\title{
Notes on the vocalizations of Black-chinned Honeyeater (Melithreptus gularis)
}

\section{Peter Boesman}

In the following we briefly analyze and compare voice of the two races of Black-chinned Honeyeater (Melithreptus gularis). We also try to quantify the extent of any vocal differences using the criteria proposed by Tobias et al. (2010), as a support for taxonomic review.

We have made use of sound recordings available on-line from Xeno Canto (XC) and Macaulay Library (ML).

Song of both races is structurally similar, a series of repeated ringing notes, often introduced by some more raspy notes. A comparison, illustrated with sonograms:

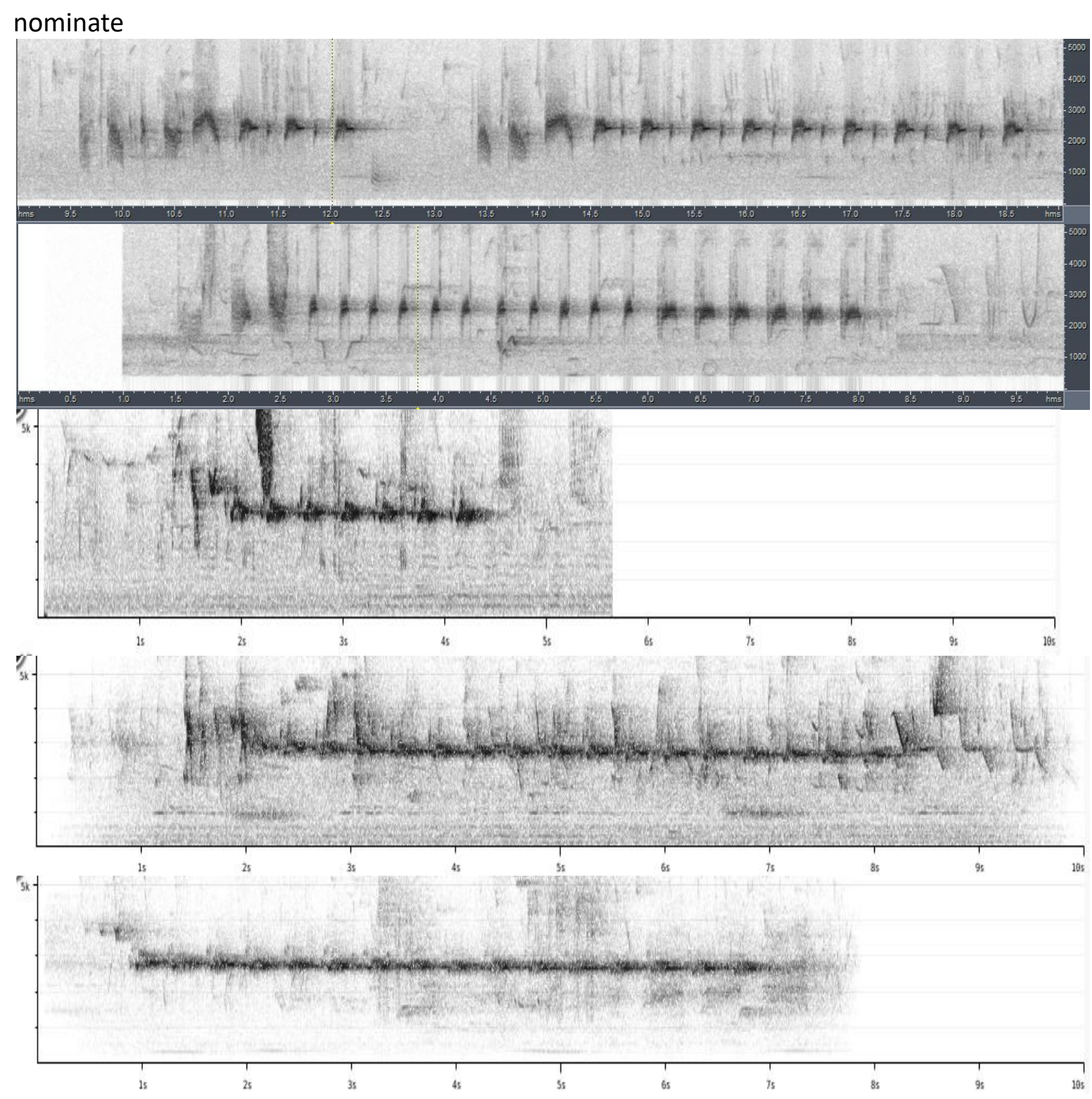




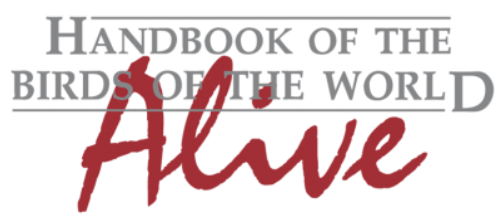

\section{ORNITHOLOGICAL NOTES}

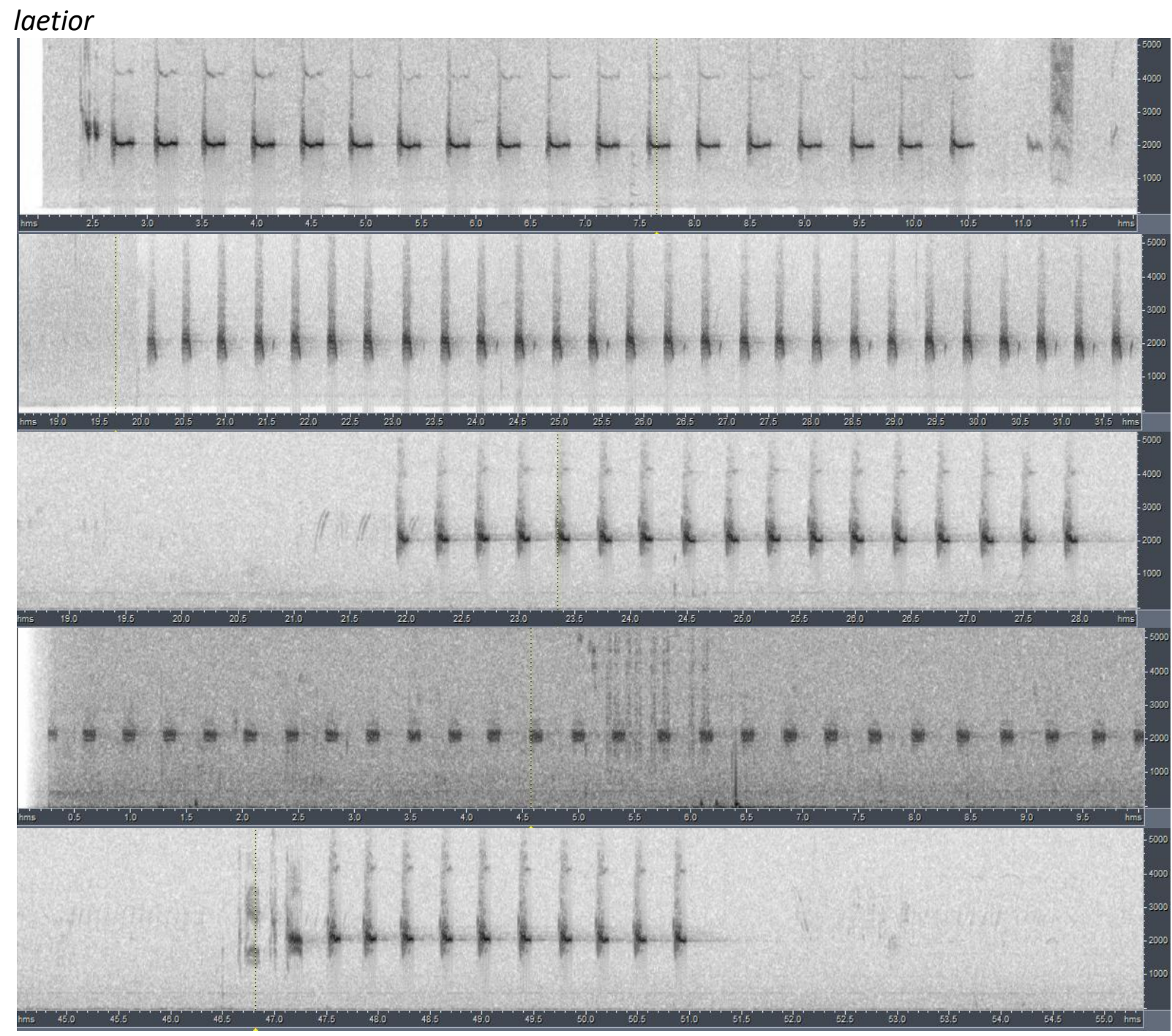

Note shapes in song of laetior are seemingly more variable than in nominate, and on average lower-pitched.

Song of nominate sounds like a ringing "rree-rree-rree..." or "rree-tup-rree-tup...". Notes of laetior sound much less ringing, duller to the ear.

Measurement of the middle frequency of repeated notes gives following results:

nominate Av $2484 \mathrm{~Hz}$ SD $92 \mathrm{~Hz}$

laetior Av $1987 \mathrm{~Hz}$ SD $48 \mathrm{~Hz}$

This leads to a calculated Effect size of 6.77 , resulting in a vocal score of 3 by application of Tobias criteria. 
This note was finalized on 8th July 2016, using sound recordings available on-line at that moment. We would like to thank in particular the sound recordists who placed their recordings for this species on XC and ML: Marc Anderson, Linda Macaulay, Mark Robbins, Nick Talbot, and the staff of Macaulay Library for forwarding the recordings of David Stewart.

\section{References}

Tobias, J.A., Seddon, N., Spottiswoode, C.N., Pilgrim, J.D., Fishpool, L.D.C. \& Collar, N.J. (2010). Quantitative criteria for species delimitation. Ibis 152(4): 724-746.

\section{Recommended citation}

Boesman, P. (2016). Notes on the vocalizations of Black-chinned Honeyeater (Melithreptus gularis). HBW Alive Ornithological Note 413. In: Handbook of the Birds of the World Alive. Lynx Edicions, Barcelona. (retrieved from http://www.hbw.com/node/1253814 on 6 December 2016). 